\title{
Adaptability and stability of canola hybrids in different sowing dates ${ }^{1}$
}

\author{
Adaptabilidade e estabilidade de híbridos de canola em diferentes épocas de \\ semeadura
}

\author{
Luiz Henrique da Silva Lima ${ }^{2 *}$, Alessandro Lucca Braccini², Carlos Alberto Scapim², Gleberson Guillen \\ Piccinin $^{3}$ and Raissa Marrafon Ponce ${ }^{4}$
}

\begin{abstract}
Canola is an important crop in the world market, mainly for its oil being used for human consumption and biodiesel production, being a great economical option for the farmer, which are the reasons to the increase in its cultivation in Brazil. This study aimed to evaluate the adaptability and stability of canola hybrids, depending on the sowing dates. The canola hybrids (Hyola 61, Hyola 76, Hyola 411 and Hyola 433) were evaluated in three sowing dates (04/10, 04/25 and 05/10) in the agricultural years of 2013 and 2014, under a randomized complete block design with five replications. The response variables analyzed were seed yield and oil content. Adaptability and stability of the hybrids were evaluated by three methods: Wricke's ecovalence (1962); confidence index (ANNICCHIARICO, 1992) and method of maximum ideal deviation (LIN; BINNS, 1988). The methodology proposed by Wricke (1962) highlighted as stable the hybrids Hyola 61 for seed yield and Hyola 411 for oil content. In the methodology proposed by Lin and Binns (1988) and Annicchiarico (1992), the hybrids with higher general adaptability and stability were Hyola 411 and 433. These hybrids presented the highest means for seed yield and oil content with predictable and responsive behavior to changes in sowing dates tested in the region of Maringá-PR.
\end{abstract}

Key words: Brassica napus L.. Oil content. Productivity.

RESUMO - A canola é uma cultura importante no mercado mundial, principalmente por seu óleo ser utilizado para consumo humano e produção de biodiesel, sendo excelente opção econômica para o agricultor, o que impulsiona o aumento de seu cultivo no Brasil. O presente trabalho objetivou avaliar a adaptabilidade e a estabilidade de híbridos de canola, em função das épocas de semeadura. Os híbridos de canola (Hyola 61, Hyola 76, Hyola 411 e Hyola 433) foram avaliados em 3 épocas de semeadura (10/04, 25/04 e 10/05) nos anos agrícolas de 2013 e 2014, sob o delineamento em blocos ao acaso com 5 repetições. As variáveis respostas analisadas foram o rendimento de sementes e o teor de óleo. A adaptabilidade e estabilidade dos híbridos foram avaliadas por três metodologias: método da ecovalência (WRICKE, 1962); índice de confiança (ANNICCHIARICO, 1992) e método do desvio do máximo ideal (LIN; BINNS, 1988). A metodologia proposta por Wricke (1962) destacou como estáveis o híbrido Hyola 61 quanto ao rendimento de sementes e Hyola 411 para o teor de óleo. Na metodologia proposta por Lin e Binns (1988) e Annicchiarico (1992), os híbridos com maior adaptabilidade geral e estabilidade foram Hyola 411 e 433. Esses híbridos apresentaram as maiores médias para o rendimento de sementes e teor de óleo, com comportamento previsível e responsivo às variações das épocas de semeadura testadas para a região de Maringá-PR.

Palavras-chave: Brassica napus L.. Teor de óleo. Produtividade.

\footnotetext{
DOI: $10.5935 / 1806-6690.20170043$

*Autor para correspondência

Recebido para publicação em 05/05/2016; aprovado em 20/07/2016

${ }^{1}$ Parte da Dissertação de Mestrado do primeiro autor apresentada ao Programa de Pós-graduação em Genética e Melhoramento da Universidade Estadual de Maringá/UEM; pesquisa realizada com suporte financeiro do Edital Universal do CNPq

${ }^{2}$ Departamento de Agronomia, Universidade Estadual de Maringá, Av. Colombo, 5790, Jardim Universitario, Maringá-PR, Brasil, 87.020-900, luizhenriquedasilvalima@gmail.com, albraccini@uol.com.br, cascapim@uem.br

32Departamento de Agronomia, Universidade Federal Rural da Amazônia, Belém-PA, Brasil, guillen.piccinin@ hotmail.com

${ }^{4}$ Programa de Pós-graduação em Agronomia, Universidade Estadual de Londrina, Londrina-PR, Londrina-PR, Brasil, raissamp@ hotmail.com
} 


\section{INTRODUCTION}

Canola was developed by Canadian plant breeders from rapeseed (Brassica napus L. var. oleifera), belonging to the family of cruciferous and the Brassica gender. Today, erucic acidfree rapeseed oil with a balanced fatty acid composition is considered optimal for nutritional purposes (salad oil, margarine), and for non-food purposes: biofuel production, tensides for detergent, biodegradable plastics and hydraulic oils (FRIEDT et al., 2007). The meal from oilseed rape after oil extraction also provides a proteinrich animal meal for all livestock and compounds of meal (WITTKOP; SNOWDON; FRIEDT, 2009).

The production of rapeseed/canola grain in the world jumped from just over 8 million tons in the 1970s to over 60 million in the early decade of 2010 (USDA, 2014). In Brazil, this growth was just under 5 thousand tonnes in 1980 to levels close to 70 thousand tonnes in early 2010 (DE MORI; TOMM; FERREIRA, 2014). Its expansion has generated new demands on the use of this raw material for the production of oil and oil byproducts such as meal and press cake. The cultivation of this oleaginous tends to increase further in Brazil due to the demand for the product in the Brazilian and European markets as well as being a good economic option for the Brazilian farmer (MARJANOVIC-JEROMELA et al., 2008; TOMM et al., 2009).

The genotype by environment interaction has been one of the principal subjects of study in breeding, allowing the generation of different methodologies for genetic improvement (ESCOBAR et al., 2011). These genotypic differences play an important role in crop adaptation for specific environments (GUNASEKERA et al., 2006).

The sowing date becomes an important agent in phenotypic characterization of plants because the plant will be affected by environmental conditions arising throughout its cycle. It is a key point in the production of this oilseed, affecting its seed yield and other agronomic characteristics for both winter canola (UZUN et al., 2009), as for spring canola (MELGAREJO et al., 2014; SHIRANI-RAD et al., 2014; TOBE et al., 2013).

Thus, it is necessary to study its relationship with genotypes, in order to better understand the phenotypic expression demonstrated by the plant in these specific environmental conditions. One of the possible alternatives to better understand it, is to identify stable cultivars with wide adaptability, through the use of adaptability and stability analyzes (CRUZ; REGAZZI; CARNEIRO, 2004).

The concept of adaptability refers to the ability of genotypes to advantageously harness environmental stimulus (CRUZ; CARNEIRO, 2003). This measure of adaptation can be performed in a general manner, comparing to the overall mean value of genotypes in the environment, or more specifically, through the partition in favorable and unfavorable environments. The term stability is conceptualized as the capacity of the genotypes to present predictable behavior in relation to environmental variations (MARIOTTI et al., 1976).

Studies evaluating the interaction between sowing date and canola cultivars are incipient in Brazil, and those that address adaptability and stability of the crop are scarce, with few international reports (MASHAYEKH; MOHAMADI; GHARANJICK, 2014; TAHIRA; KHAN; AMJAD, 2013).

Therefore, seeking to expand the knowledge about the agronomic potential of this crop with focus on data of oil content and seed yield, this work was carried out with aim to evaluate adaptability and stability of canola hybrids, according to sowing dates in the city of Maringá, Parana State.

\section{MATERIAL AND METHODS}

The experiments were carried out in the Iguatemi Experimental Farm (FEI) part of the Center for Agricultural Sciences, State University of Maringá (UEM), located in the city of Maringá, northwestern of Paraná State. FEI is located at latitude of $23^{\circ} 25^{\prime}$ south and longitude $51^{\circ} 57^{\prime}$ west of Greenwich, with an average altitude of $540 \mathrm{~m}$.

The experimental area is on a dystrophic Red Argisol, medium texture. The soil was analyzed for chemical characteristics and fertilization was carried out in accordance with the technical recommendations for the cultivation of canola (TOMM et al., 2009).

Evaluated sowing dates were as follows: April 10, April 25 and the last one on May 10, in the years 2013 and 2014. Each period constitutes an environment where the hybrids Hyola 61, Hyola 76, Hyola 411 and Hyola 433, belonging to different maturity groups (Table 1), were tested.

The experimental design used in each environment was the randomized blocks with 5 replications. The experimental plots consisted of six rows of five meters in length, spaced $0.45 \mathrm{~m}$ apart, totaling a useful area of $3.6 \mathrm{~m}^{2}$, in which it was received the treatments.

Cultural practices such as nitrogen and sulfur fertilization in coverage, pests, diseases and weeds control were conducted in all experimental units during the development of the crop, according to recommendations of Tomm et al. (2009). At the Laboratory of Seed Technology of the Applied Research Center for Agriculture (NUPAGRI) of UEM, the following response variables were quantified: 
Table 1 - Characteristics of the evaluated canola hybrids

\begin{tabular}{|c|c|c|c|c|}
\hline \multirow{2}{*}{ Characteristics } & \multicolumn{4}{|c|}{ Canola hybrids } \\
\hline & Hyola 61 & Hyola 76 & Hyola 411 & Hyola 433 \\
\hline Emergence to early flowering (days) & $53-77$ & $61-81$ & $59-65$ & $58-67$ \\
\hline Flowering duration (days) & $28-52$ & $24-62$ & $30-72$ & $28-73$ \\
\hline Emergence to maturity (days) & $123-155$ & $120-164$ & $120-150$ & $120-150$ \\
\hline Cicle & Medium & Long & Early & Early \\
\hline Plant height $(\mathrm{cm})$ & $88-136$ & $126-159$ & $128-139$ & $124-131$ \\
\hline $\begin{array}{l}\text { Reaction to the disease "blackleg" } \\
\text { (Leptosphaeria maculans) }\end{array}$ & Polygenic resistance & Polygenic resistance & Polygenic resistance & Polygenic resistance \\
\hline
\end{tabular}

Seed yield: the water content in the seeds was measured up after harvest, on a wet basis. Subsequently, the harvested plot was extrapolated to 1 hectare, with correction of water content in wet basis to $9 \%$, and the results were expressed in $\mathrm{kg} \mathrm{ha}^{-1}$. Oil content: the Soxhlet's method was used, through the Soxhlet extractor and petroleum ether as solvent, with reflux of 6 hours (IAL, 2008). The oil content was determined by weight difference, being presented as a percentage.

The collected data were submitted to individual analysis of variance for each environment after meeting the basic assumptions for analysis. The joint analysis of variance was studied in which the effects of hybrids and environments have been considered fixed. The homogeneity of the residual square means for each environment was compared by the Bartlett's test. The hybrids were compared by Scott-Knott's test at $5 \%$ probability.

Adaptability and stability of the hybrids were evaluated by parametric methodology: Wricke's ecovalence (1962), confidence index (ANNICCHIARICO, 1992) and the non-parametric methodology: method of maximum ideal deviation (LIN; BINNS, 1988).

The Ecovalence index $\left(\omega_{i}\right)$ of Wricke (1962) was calculated as follows:

$\omega_{i}=r \sum_{j}\left(Y_{i j}-\bar{Y}_{i .}-\bar{Y}_{. j}+\bar{Y}_{. .}\right)^{2}$

Where, $\omega_{i}$ : contribution of the hybrid $i$ in the total variance of the interaction; $Y_{i j}$ : mean of the plot that received the hybrid $\mathrm{i}$ in the environment $\mathrm{j} ; \bar{Y}_{i}$ : mean of the hybrid $\mathrm{i}$ for all environments; $\bar{Y}_{J}$ : mean of the environment $\mathrm{j}$ for all hybrids; $\bar{Y}$ : overall mean.

In the methodology proposed by Annicchiarico (1992), it was estimated the confidence index:

$I_{i}=\hat{\mu}_{i}-Z_{(I-\alpha)} \hat{\sigma}_{Z i}$

Where, $I_{i}$ : confidence index, expressed in percentage; $\hat{\mu}_{i}$ : mean relative to the hybrid $\mathrm{i}$ expressed as a percentage; $\mathrm{Z}$ : percentage (1- $\alpha)$ of the cumulative normal distribution function; $\alpha$ : significance level; $\hat{\sigma}_{Z i}$ : standard deviation of the percentage values of the hybrid i. It was considered $Z_{(1-\alpha)}=0.2734$, which corresponds to the variable's value of a $\mathrm{Z}$ distribution, for $\alpha=0,25$.

In the Lin and Binns methodology (1988) the estimator $P_{i}$ was calculated as a measure of stability and general adaptability:

$P_{i}=\frac{\sum_{j=1}^{a}\left(Y_{i j}-m_{j}\right)^{2}}{2 a}$

Where, $P_{i}$ : estimative of the stability and adaptability parameter of the hybrid $\mathrm{i}$; $Y_{i j}$ : the yield of the $\mathrm{i}^{\text {th }}$ - hybrid in the $\mathrm{j}^{\text {th }}$ environment; $\mathrm{M}_{\mathrm{j}}$ : maximum response observed among all hybrids in the environment $\mathrm{j}$; $\mathrm{a}$ : number of environments.

This value was partitioned into two components attributed to: genetic factors $\left(P_{i g}\right)$ and hybrid x environment interaction factors $\left(P_{i g a}\right)$. The computational applicative in genetics and statistics GENES (CRUZ, 2013) was used in assistance to the analysis. The overall mean value of the hybrids on sowing dates for both variables was used as a measure of adaptation.

\section{RESULTS AND DISCUSSION}

The joint analysis of variance of sowing dates is presented in Table 2. It was found homogeneity of variance for the character oil content, however, was not observed for seed yield. In this case, the degrees of freedom of the error and hybrids $\mathrm{x}$ environments interaction were adjusted according to Cochran (1954).

The mean values analyzed for seed yield and oil content were superior than those found by Melgarejo et al. (2014), who observed an overall mean of $1,058.5 \mathrm{~kg} \mathrm{ha}^{-1}$ and $38.2 \%$ respectively, working in Marechal Cândido Rondon city, western Paraná State. The values of coefficient of variation were $13.51 \%$ and $5.97 \%$ for seed yield and oil 
Table 2 - Joint analysis of 4 canola hybrids evaluated in six different environments for the response variables seed yield (SY) and oil content in seeds (OIL)

\begin{tabular}{lcccc}
\hline \multirow{2}{*}{ Sources of Variation } & \multicolumn{2}{c}{$\mathrm{SY}\left(\mathrm{kg} \mathrm{ha}^{-1}\right)$} & \multicolumn{2}{c}{ OIL (\%) } \\
\cline { 2 - 5 } & DF & Mean Square & DF & Mean Square \\
\hline Blocks/ Sowing dates & 24 & $20,494.86$ & 3 & 10.88 \\
Hybrids (H) & 3 & $117,012.19^{*}$ & 5 & $22.07^{*}$ \\
Sowing dates (D) & 5 & $119,695.59^{*}$ & 15 & $15.26^{\text {ns }}$ \\
H x D & $12^{1}$ & $52,256.71^{*}$ & 72 & $29.79^{*}$ \\
Error & $57^{1}$ & $15,483.70$ & & 5.50 \\
C.V. $(\%)$ & & 13.51 & & 5.97 \\
Overall Mean & & $1,081.01$ & 39.26 \\
\hline
\end{tabular}

${ }^{1}$ Adjusted degrees of freedom according to Cochran (1954); * Significant at 5\% probability by the $\mathrm{F}$ test; ${ }^{\text {ns }}$ Non Significant at $5 \%$ probability by the $\mathrm{F}$ test

content, respectively, and are in agreement with the values found by Kaefer et al. (2014).

The joint analysis showed significance $(\mathrm{P}<0.05)$ for hybrids and the interaction hybrids $\mathrm{x}$ sowing dates (H x D) of the characteristics seed yield and oil content. Considering the source of variance hybrids, it was found evidence for the existance of mean genetic differences among the analyzed hybrids. Regarding the source of variance sowing dates, these did not differ for oil content in canola seed $(\mathrm{P}>0.05)$, but differed for seed yield $(\mathrm{P}<0.05)$. This can be explained by several factors, such as small differences in cultural practices, differences among the climatic components, and among the agricultural years of 2013 and 2014. In other studies, environmental variation was the largest component of the total variation for seed yield, with examples of winter (MARJANOVICJEROMELA et al., 2011; NOWOSAD et al., 2016) and spring genotypes (TOBE et al., 2013) of canola.

The presence of $\mathrm{H} \times \mathrm{D}$ interaction means that the sowing dates produced a differential effect in the response of hybrids for both traits. Thus in order to identify hybrids less affected by environmental variation, the methods of adaptability and stability was used.
The results of Wricke's method (1962) are shown in Table 3. In this methodology, the $\omega_{i}$ is equal to the sum of squares of the hybrid $\mathrm{x}$ sowing dates interaction. A hybrid displays low Ecovalence when contributes little to the interaction, in other words, the hybrid shows a similar response to the mean of all the tested genotypes having more phenotypic stability.

The hybrids Hyola 61 and 76 presented lower Ecovalence, demonstrating greater stability of seed yield in the evaluated environments. For oil content, Hyola 411 showed greater stability, due to the lower contribution of the total Ecovalence. Hyola 76 contributed more to the $\mathrm{H}$ $\mathrm{x} \mathrm{D}$ interaction, giving it low stability as response to the evaluated sowing dates. It is interesting that the characters seed yield and oil content, exhibit above average behavior in the environments, which was used as reference in this study both to the stability as to the adaptability parameter.

It is verified in Table 4, the performance of stability and adaptability of hybrids in different sowing dates, according to the Annicchiarico methodology (1992). For seed yield and oil content, the hybrids Hyola 411 and 433 indicated the top recommendation indices of general

Table 3 - Ecovalence $\left(\omega_{\mathrm{i}}\right)$ for canola hybrids to seed yield (SY) and oil content in seeds (OIL) according to the Wricke's method (1962)

\begin{tabular}{lccrrrr}
\hline \multirow{2}{*}{ Canola hybrids } & \multicolumn{3}{c}{ SY } & \multicolumn{3}{c}{ OIL } \\
\cline { 2 - 7 } & Means $^{1}\left(\mathrm{~kg} \mathrm{ha}^{-1}\right)$ & Ecovalence $\left(\omega_{\mathrm{i}}\right)$ & $\omega_{\mathrm{i}}(\%)$ & Means $^{1}(\%)$ & ${\text { Ecovalence }\left(\omega_{\mathrm{i}}\right)}_{1} \omega_{\mathrm{i}}(\%)$ \\
\hline Hyola 61 & $1,048.74 \mathrm{~A}$ & $52,881.19$ & 8.43 & $38.84 \mathrm{~A}$ & 89.80 & 20.10 \\
Hyola 76 & $1,009.32 \mathrm{~A}$ & $70,386.30$ & 11.22 & $38.26 \mathrm{~A}$ & 172.66 & 38.64 \\
Hyola 411 & $1,140.66 \mathrm{~A}$ & $142,697.87$ & 22.76 & $39.97 \mathrm{~A}$ & 36.51 & 8.17 \\
Hyola 433 & $1,125.31 \mathrm{~A}$ & $361,115.16$ & 57.59 & $39.99 \mathrm{~A}$ & 147.90 & 33.10 \\
Total & - & $627,080.51$ & 100.00 & - & 446.88 & 100.00 \\
Overall Mean & $1,081.01$ & - & - & 39.26 & - & - \\
\hline
\end{tabular}

${ }^{1}$ Means followed by the same capital letter in the column do not differ by the Scott-Knott test at $5 \%$ probability 
adaptability and stability as well as values above the overall mean in the environments.

In this methodology, the index $\left(\mathrm{I}_{\mathrm{i}}\right)$ is generated from the mean values of the genotypes, with regards to the average of environments. It expresses the stability and also the general adaptability, with the highest values found by the genotypes that present the highest mean percent $\left(\mu_{\mathrm{i}}\right)$ and the lowest deviation $\left(\sigma_{\mathrm{zi}}\right)$, which are related to the highest recommendation indices (CRUZ; CARNEIRO, 2003).

The hybrids presented good performance in evaluated sowing dates, for exhibitting acceptable confidence indices, close to $100 \%$, which demonstrates at worst case, values $10 \%$ lower than the overall mean. Hyola 411 has a seed yield, on average, $1.06 \%$ higher than the mean environments in the most adverse conditions, with $75 \%$ confidence. Thus, these early maturing hybrids proved to be more stable, with less likelihood of failure in the farmer's choice.

Through the method of Lin and Binns (1988) the parameter $P_{i}$ was obtained for the environments in general, as well as its partition in genetic parts $\left(P_{i g}\right)$ and interaction $\left(P_{i g a}\right)$, described in Table 5. The results indicate that the smaller the value of parameter $P_{i}$, the greater the capacity of the genotype to produce minimal variation in the phenotype for the different sowing dates tested.

The hybrid Hyola 433 showed general adaptability and stability, presenting considerable genetic effect on expression of seed yield, besides obtaining mean higher than the overall mean. Hyola 411, also stood out, with the highest yield, however, its behavior was poorly explained by genetic factors. For oil content, Hyola 411 showed lower value of $\mathrm{P}_{\mathrm{i}}$, configuring itself as the most stable and with broad adaptation, exceeding the overall mean.

As with the Annicchiarico methodology (1992), it is mentioned once again the position of the early hybrids Hyola 411 and 433 as the most stable and with broad adaptation to the evaluated dates, setting themselves as good choices for planting in the region. Hyola 76 had the lowest seed yield and oil content adaptability and stability, compared to the sowing dates. These results disagree with the Wricke's methodology (1962) for seed yield in agreement, however, regarding the oil content.

Over time many biometric models have been proposed by researchers. The difference between methods originates from the very concepts of adaptability, stability and in the biometric procedures used to measure it (CARGNELUTTI FILHO et al., 2007). The existing differences in results among different methods occurs in most studies. For some authors, it brings more trust to indicate if the same results were found in different methods rather than just one (MARQUES et al., 2011; PELÚZIO et al., 2008; VASCONCELOS et al., 2015). Therefore, it is advisable to use methodologies for different statistical classifications, as used in this study.

Table 4 - General adaptability and stability measures of canola hybrids for seed yield and oil content according to the Annicchiarico's method (1992)

\begin{tabular}{|c|c|c|c|c|}
\hline \multicolumn{5}{|c|}{ Seed yield } \\
\hline Canola hybrids & Means $^{1}\left(\mathrm{~kg} \mathrm{ha}^{-1}\right)$ & $\hat{\mu}_{i}(\%)$ & $\hat{\sigma}_{\mathrm{Zi}}(\%)$ & $\mathrm{I}_{\mathrm{i}}^{2}(\%)$ \\
\hline Hyola 61 & $1,048.74 \mathrm{~A}$ & 97.05 & 4.23 & 94.20 \\
\hline Hyola 76 & $1,009.32 \mathrm{~A}$ & 93.61 & 4.37 & 90.66 \\
\hline Hyola 411 & $1,140.66 \mathrm{~A}$ & 105.63 & 6.77 & 101.06 \\
\hline Hyola 433 & $1,125.31 \mathrm{~A}$ & 103.71 & 10.12 & 96.88 \\
\hline Overall Mean & $1,081.01$ & - & - & - \\
\hline \multicolumn{5}{|c|}{ Oil content } \\
\hline Canola hybrids & Means $^{1}(\%)$ & $\hat{\mu}_{i}(\%)$ & $\hat{\sigma}_{\mathrm{Zi}}(\%)$ & $\mathrm{I}_{\mathrm{i}}^{2}(\%)$ \\
\hline Hyola 61 & $38.84 \mathrm{~A}$ & 98.85 & 4.89 & 95.55 \\
\hline Hyola 76 & $38.26 \mathrm{~A}$ & 97.50 & 6.55 & 93.09 \\
\hline Hyola 411 & $39.97 \mathrm{~A}$ & 101.77 & 3.10 & 99.67 \\
\hline Hyola 433 & $39.99 \mathrm{~A}$ & 101.88 & 6.16 & 97.72 \\
\hline Overall Mean & 39.26 & - & - & - \\
\hline
\end{tabular}

${ }^{1}$ Means followed by the same capital letter in the column do not differ by the Scott-Knott test at $5 \%$ probability. ${ }^{2} \alpha=0.25$ of probability 
Table 5 - General adaptability and stability measures of canola hybrids for seed yield and oil content according to the Lin and Binns' method (1988)

\begin{tabular}{|c|c|c|c|c|c|}
\hline \multicolumn{6}{|c|}{ Seed yield } \\
\hline \multirow{2}{*}{ Canola hybrids } & \multirow{2}{*}{$\operatorname{Means}^{1}\left(\mathrm{~kg} \mathrm{ha}^{-1}\right)$} & \multirow{2}{*}{$P_{i}$} & \multicolumn{2}{|c|}{ Deviation } & \multirow{2}{*}{$\%$ (Genetic) } \\
\hline & & & Genetic $\left(\mathrm{P}_{\mathrm{ig}}\right)$ & Interaction $\left(\mathrm{P}_{\text {iga }}\right)$ & \\
\hline Hyola 61 & $1,048.74 \mathrm{~A}$ & $18,360.41$ & $11,322.07$ & $7,038.35$ & 61.67 \\
\hline Hyola 76 & $1,009.32 \mathrm{~A}$ & $26,462.13$ & $18,032.46$ & $8,429.67$ & 68.14 \\
\hline Hyola411 & $1,140.66 \mathrm{~A}$ & $9,551.46$ & $1,715.16$ & $7,836.30$ & 17.96 \\
\hline Hyola 433 & $1,125.31 \mathrm{~A}$ & $4,508.51$ & $2,731.52$ & $1,776.99$ & 60.59 \\
\hline Overall Mean & $1,081.01$ & - & - & - & - \\
\hline \multicolumn{6}{|c|}{ Oil content } \\
\hline \multirow{2}{*}{ Canola hybrids } & \multirow{2}{*}{ Means $^{1}(\%)$} & \multirow{2}{*}{$P_{i}$} & \multicolumn{2}{|c|}{ Deviation } & \multirow{2}{*}{$\%$ (Genetic) } \\
\hline & & & Genetic $\left(\mathrm{P}_{\mathrm{ig}}\right)$ & Interaction $\left(\mathrm{P}_{\text {iga }}\right)$ & \\
\hline Hyola 61 & $38.84 \mathrm{~A}$ & 4.88 & 2.72 & 2.16 & 55.69 \\
\hline Hyola 76 & $38.26 \mathrm{~A}$ & 9.08 & 4.21 & 4.87 & 46.39 \\
\hline Hyola411 & $39.97 \mathrm{~A}$ & 1.41 & 0.72 & 0.69 & 51.05 \\
\hline Hyola 433 & $39.99 \mathrm{~A}$ & 2.09 & 0.69 & 1.40 & 33.04 \\
\hline Overall Mean & 39.26 & - & - & - & - \\
\hline
\end{tabular}

${ }^{1}$ Means followed by the same capital letter in the column do not differ by the Scott-Knott test at $5 \%$ probability

\section{CONCLUSIONS}

1. In the methodology proposed by Wricke (1962), the most outstanding hybrid for phenotypic stability in seed yield was Hyola 61. For oil content, the hybrid Hyola 411 was the most stable;

2. In the methodology proposed by Lin and Binns (1988) and Annicchiarico (1992), the hybrids with general adaptability and behavioral stability were Hyola 411 and 433. These hybrids showed the highest means for seed yield and oil content, with predictable behavior and responsive to changes in sowing dates tested in the region of Maringá-PR.

\section{ACKNOWLEDGEMENT}

To the Conselho Nacional de Desenvolvimento Científico e Tecnológico (CNPq) for providing resources (Proc.445671/2014-9) for the development of this research. To EMBRAPA Trigo (CNPT) by sending hybrid seeds. To the officials of the Experimental Farm of Iguatemi (UEM), for their assistance in conducting the experiment.

\section{REFERENCES}

ANNICCHIARICO, P. Cultivar adaptation and recomendation from alfafa trials in Northern Italy. Journal of Genetics and Plant Breeding, v. 46, n. 1, p. 269-278, 1992.

CARGNELLUTI FILHO, A. et al. Comparação de métodos de adaptabilidade e estabilidade relacionados à produtividade de grãos de cultivares de milho. Bragantia, v. 66, n. 4, p. 571-578, 2007.

COCHRAN, W. G. The combination of estimates from different experiments. Biometrics, v. 10, n. 1, p. 101-129, 1954.

CRUZ, C. D. Genes: a software package for analysis in experimental statistics and quantitative genetics. Acta Scientiarum. Agronomy, v. 35, n. 3, p. 271-276, 2013.

CRUZ, C. D.; CARNEIRO, P. C. S. Modelos biométricos aplicados ao melhoramento genético. Viçosa, MG: Editora UFV, 2003. 585 p. v. 2.

CRUZ, C. D.; REGAZZI, A. J.; CARNEIRO, P. C. S. Modelos biométricos aplicados ao melhoramento genético. Viçosa, MG: Editora UFV, 2004. 480 p.

DE MORI, C.; TOMM, G. O.; FERREIRA, P. E. P. Aspectos econômicos e conjunturais da cultura da canola no mundo e no Brasil. Passo Fundo: Embrapa Trigo, 2014. 36 p. (Embrapa 
Trigo. Documentos online, 149). Disponível em: <http://www. cnpt.embrapa.br/biblio/do/p_do149.htm>. Acesso em: $17 \mathrm{dez}$. 2014.

ESCOBAR, M. et al. Genotype $\times$ environment interaction in canola (Brassica napus L.) seed yield in Chile. Chilean Journal of Agricultural Research, v. 71, n. 2, p. 175-186, 2011.

FRIEDT, W. et al. Plant breeding: assessment of genetic diversity in crop plants and its exploitation in breeding. Progress in Botany, v. 168, p. 152-177, 2007

GUNASEKERA, C. P. et al. Genotype by environment interactions of Indian mustard (Brassica juncea $\mathrm{L}$ ) and canola (Brassica napus L.) in Mediterranean-type environments: I. Crop growth and seed yield. European Journal of Agronomy, v. 25, n. 1, p. 1-12, 2006.

INSTITUTO ADOLF LUTZ. Métodos físico-químicos para análise de alimentos. São Paulo, 2008. 1020 p.

KAEFER, J. E. et al. Produtividade de sementes e componentes de produção da canola de acordo com fontes e doses de nitrogênio. Pesquisa Agropecuária Brasileira, v. 49, n. 4, p. 273-280, 2014

LIN, C. S.; BINNS, M. R. A superiority measure of cultivar performance for cultivars $\mathrm{x}$ location data. Canadian Journal of Plant Science, v. 68, n. 1, p. 193-198, 1988.

MARIOTTI, I. A. et al. Análisis de estabilidad y adaptabilidad de genotipos de caña de azúcar. I. Interacciones dentro de una localidad experimental. Revista Agronómica del Nordeste Argentino, v. 13, n. 14, p. 105-127, 1976.

MARJANOVIC-JEROMELA,A. et al. Genotype by environment interaction for seed yield per plant in rapeseed using AMMI model. Pesquisa Agropecuária Brasileira, v. 46, n. 2, p. 174181,2011

MARJANOVIC-JEROMELA, A. et al. Oil yield stability of winter rapeseed (Brassica napus L.) genotypes. Agriculturae Conspectus Scientificus, v. 73, n. 4, p. 217-220, 2008.

MARQUES, M. C. et al. Adaptabilidade e estabilidade de genótipos de soja em diferentes épocas de semeadura. Bioscience Journal, v. 27, n. 1, p. 59-69, 2011.

MASHAYEKH, A.; MOHAMADI, A.; GHARANJICK, S. Evaluation of canola genotypes for yield stability in the four regions in Iran. Bulletin of Environment, Pharmacology and Life Sciences, v. 3, n. 11, p. 123-128, 2014.

MELGAREJO, A. M. A. et al. Características agronômicas e teor de óleo da canola em função da época de semeadura.
Revista Brasileira de Engenharia Agrícola e Ambiental, v. 18, n. 9, p. 934-938, 2014.

NOWOSAD, K. et al. Genotype by environment interaction for seed yield in rapeseed (Brassica napus L.) using additive main effects and multiplicative interaction model. Euphytica, v. 208 , n. 1 , p. $187-194,2016$

PELÚZIO, J. M. et al. Adaptabilidade e estabilidade de cultivares de soja em quatro épocas de semeadura no sul do Estado do Tocantins. Revista Ceres, v. 55, n. 1, p. 34-40, 2008.

SHIRANI-RAD, A. et al. Effects of planting date on spring rapeseed (Brassica napus L.) cultivars under different irrigation regimes. Turkish Journal of Field Crops, v. 19, n. 2, p. 153-157, 2014.

TAHIRA, A. R.; KHAN, M. A.; AMJAD, M. Stability analysis of canola (Brassica napus) genotypes in Pakistan. Global Advanced Research Journal of Agricultural Science, v. 10, n. 2, p. 270-275, 2013.

TOBE, A. et al. Effect of sowing date on some phenological stages and oil contents in spring canola (Brassica napus, L.) cultivars. Middle-East Journal of Scientific Research, v. 13, n. 9, p. 1202-1212, 2013.

TOMM, G. O. et al. Tecnologia para produção de canola no Rio Grande do Sul. Passo Fundo: Embrapa Trigo, 2009. 41 p. (Embrapa Trigo. Documentos Online, 113). Disponível em: <http://www.cnpt.embrapa.br/biblio/do/p_do113.htm>. Acesso em: 10 jan. 2015.

UNITED STATES DEPARTMENT OF AGRICULTURE. Foreign Agricultural Service. Production, supply, and distribution online. Disponível em: <http://apps.fas.usda.gov/ psdonline>. Acesso em: 25 jul. 2014.

UZUN, B. et al. Sowing date effects on growth, flowering, seed yield and oil content of canola cultivars. Asian Journal of Chemistry, v. 21, n. 3, p. 1957-1965, 2009.

VASCONCELOS, F. M. T. et al. Adaptabilidade e estabilidade de genótipos eretos de amendoim cultivados nas regiões Nordeste e Centro-Oeste. Ciência Rural, v. 45, n. 8, p. 13751380, 2015.

WITTKOP, B.; SNOWDON, R.; FRIEDT, W. Status and perspectives of breeding for enhanced yield and quality of oilseed crops for Europe. Euphytica, v. 170, p. 131-140, 2009.

WRICKE, G. Uber eine method zur erfassung der okologischen streubreit in feldversuchen. Zeitschrift für Pflanzenzucht, v. 47 , p. $92-96,1962$. 